\title{
No observed effect of ocean acidification on nitrogen biogeochemistry in a summer Baltic Sea plankton community
}

\author{
Allanah J. Paul ${ }^{1}$, Eric P. Achterberg ${ }^{1,2}$, Lennart T. Bach ${ }^{1}$, Tim Boxhammer ${ }^{1}$, Jan Czerny ${ }^{1}$, Mathias Haunost ${ }^{1}$, \\ Kai-Georg Schulz ${ }^{1,3}$, Annegret Stuhr ${ }^{1}$, and Ulf Riebesell ${ }^{1}$ \\ ${ }^{1}$ GEOMAR Helmholtz Centre for Ocean Research Kiel, Düsternbrooker Weg 20, 24105 Kiel, Germany \\ ${ }^{2}$ National Oceanography Centre Southampton, European Way, University of Southampton, Southampton, SO14 3ZH, UK \\ ${ }^{3}$ Southern Cross University, Military Road, East Lismore, NSW 2480, Australia \\ Correspondence to: Allanah J. Paul (apaul@geomar.de)
}

Received: 5 October 2015 - Published in Biogeosciences Discuss.: 30 October 2015

Revised: 17 May 2016 - Accepted: 29 May 2016 - Published: 7 July 2016

\begin{abstract}
Nitrogen fixation by filamentous cyanobacteria supplies significant amounts of new nitrogen $(\mathrm{N})$ to the Baltic Sea. This balances $\mathrm{N}$ loss processes such as denitrification and anammox, and forms an important $\mathrm{N}$ source supporting primary and secondary production in N-limited postspring bloom plankton communities. Laboratory studies suggest that filamentous diazotrophic cyanobacteria growth and $\mathrm{N}_{2}$-fixation rates are sensitive to ocean acidification, with potential implications for new N supply to the Baltic Sea. In this study, our aim was to assess the effect of ocean acidification on diazotroph growth and activity as well as the contribution of diazotrophically fixed $\mathrm{N}$ to $\mathrm{N}$ supply in a natural plankton assemblage. We enclosed a natural plankton community in a summer season in the Baltic Sea near the entrance to the Gulf of Finland in six large-scale mesocosms (volume $\sim 55 \mathrm{~m}^{3}$ ) and manipulated $f \mathrm{CO}_{2}$ over a range relevant for projected ocean acidification by the end of this century (average treatment $f \mathrm{CO}_{2}: 365-1231 \mu \mathrm{atm}$ ). The direct response of diazotroph growth and activity was followed in the mesocosms over a 47 day study period during $\mathrm{N}$-limited growth in the summer plankton community. Diazotrophic filamentous cyanobacteria abundance throughout the study period and $\mathrm{N}_{2}$-fixation rates (determined only until day 21 due to subsequent use of contaminated commercial ${ }^{15} \mathrm{~N}-\mathrm{N}_{2}$ gas stocks) remained low. Thus estimated new $\mathrm{N}$ inputs from diazotrophy were too low to relieve $\mathrm{N}$ limitation and stimulate a summer phytoplankton bloom. Instead, regeneration of organic $\mathrm{N}$ sources likely sustained growth in the plankton community. We could not detect significant $\mathrm{CO}_{2}$-related differences in neither inorganic nor organic $\mathrm{N}$ pool sizes, or partic-
\end{abstract}

ulate matter $\mathrm{N}$ : P stoichiometry. Additionally, no significant effect of elevated $\mathrm{CO}_{2}$ on diazotroph activity was observed. Therefore, ocean acidification had no observable impact on $\mathrm{N}$ cycling or biogeochemistry in this N-limited, post-spring bloom plankton assemblage in the Baltic Sea.

\section{Introduction}

Nitrogen $(\mathrm{N})$ is an essential element for cell functioning in the biosphere due to its presence in many important biomolecules such as nucleic acids and proteins. However, in many marine ecosystems $\mathrm{N}$ is considered the limiting nutrient for important cellular processes in phytoplankton ( Vitousek and Howarth, 1991), as indicated through stimulation carbon fixation and pigment synthesis through addition of inorganic N (e.g. Moore et al., 2008, 2013). This low N availability also prevails in post-spring bloom plankton communities in the Baltic Sea, as the nitrate pool is exhausted during the spring bloom, leaving behind an excess of dissolved inorganic phosphorus (Wasmund et al., 2001). Consequently, filamentous diazotrophic ( $\mathrm{N}_{2}$-fixing) cyanobacteria, in particular heterocystous Nodularia spumigena and Aphanizomenon flos-aquae, capitalise on this excess phosphate and increasing water column temperatures in summer months (Kononen et al., 1996; Pliński and Jóźwiak, 1999; Wasmund, 1997) and commonly form extensive blooms and surface aggregations (e.g. Kahru and Elmgren, 2014). The atmospheric nitrogen gas $\left(\mathrm{N}_{2}\right)$ fixed by these heterocystous cyanobacteria during the summer months forms a key $\mathrm{N}$ source for the 
wider plankton community in the Baltic Sea, since a significant fraction of the fixed $\mathrm{N}$ can be released as ammonium (Ohlendieck et al., 2000; Ploug et al., 2010; Stal et al., 2003; Wannicke et al., 2013) and dissolved organic N compounds (Ohlendieck et al., 2000, 2007; Wannicke et al., 2013). Thus in addition to $\mathrm{N}$ in diazotroph biomass, newly fixed $\mathrm{N}$ is also available for direct assimilation by phytoplankton and bacteria and is estimated to support up to $20-45 \%$ of annual primary production in the Baltic Sea (Gustafsson et al., 2013). This new $\mathrm{N}$ input partly replenishes $\mathrm{N}$ loss processes such as anammox and denitrification in the deep anoxic basins (Vahtera et al., 2007). Furthermore, this fixed $\mathrm{N}$ can also be directly transferred to higher trophic levels through grazing by zooplankton (Engström-Öst et al., 2011; Hogfors et al., 2014; Wannicke et al., 2013).

Changes in seawater carbonate chemistry due to increased atmospheric $\mathrm{CO}_{2}$ concentrations are expected to induce changes in phytoplankton physiology. The associated decrease in seawater $\mathrm{pH}$ is called ocean acidification. Numerous single-strain culture studies have investigated the physiological responses of a variety of diazotrophic organisms and generally indicated increased $\mathrm{N}_{2}$-fixation and diazotroph growth rates under elevated $\mathrm{CO}_{2}$ (Barcelos e Ramos et al., 2007; Fu et al., 2008; Hutchins et al., 2007; Kranz et al., 2010; Levitan et al., 2007), with contrasting evidence under iron limitation (Shi et al., 2012) and with freshwater strains of A. flos-aquae (Yamamoto and Nakahara, 2005). Three studies on the common Baltic Sea species, N. spumigena, produced contrasting results with two studies under phosphate repletion suggesting a negative effect (Czerny et al., 2009; Eichner et al., 2014), and one study, under low inorganic phosphate availability, indicating a positive effect (Wannicke et al., 2012) of increased $\mathrm{CO}_{2}$ on growth and $\mathrm{N}_{2}$ fixation rates. This discrepancy may, however, be due to differences in phosphate availability (Eichner et al., 2014). Considering the contribution of diazotrophs to the $\mathrm{N}$ budget and primary productivity in the Baltic Sea, it is vital to understand the influence of future changes in $p \mathrm{CO}_{2}$ on new $\mathrm{N}$ inputs by diazotrophs.

In this mesocosm study, our aim was to assess diazotroph growth and rates of $\mathrm{N}_{2}$-fixation under a range of $\mathrm{CO}_{2}$ concentrations in a natural plankton community. $\mathrm{N}$ limitation of phytoplankton growth was reported in the study area in the Finland Archipelago Sea (Kirkkala et al., 1997; Tamminen and Andersen, 2007). By utilising the naturally occurring low $\mathrm{N}$ conditions in the Baltic Sea we wanted to examine the importance of new $\mathrm{N}$ inputs by diazotrophic organisms to the wider plankton community $\mathrm{N}$ supply under projected future ocean acidification scenarios.

\section{Materials and methods}

\subsection{Experimental set-up and sampling}

The study took place in the period between June and $\mathrm{Au}-$ gust 2012 in Tvärminne Storfjärden, which is situated in the Archipelago Sea on the southwestern tip of Finland. Six pelagic mesocosms (total volume $\sim 55 \mathrm{~m}^{3}$, Kiel OffShore Mesocosms for future Ocean Simulations - KOSMOS, Riebesell et al., 2013) were deployed on 12 June 2012 (day of experiment $-10=t-10$, i.e. 10 days before $\mathrm{CO}_{2}$ manipulation) and moored at $59^{\circ} 51.5^{\prime} \mathrm{N}, 23^{\circ} 15.5^{\prime} \mathrm{E}$. The cylindrical mesocosm bags of $2 \mathrm{~m}$ in diameter extended from $1.5 \mathrm{~m}$ above to $19 \mathrm{~m}$ below the water surface and were closed at the bottom by a $2 \mathrm{~m}$ long sediment trap funnel on $t-5$. A $3 \mathrm{~mm}$ net was used to exclude larger organisms or particles before mesocosm closure.

A gradient of $\mathrm{CO}_{2}$ treatments across the mesocosms was established over a 4 day period by additions of filtered $(50 \mu \mathrm{m}), \mathrm{CO}_{2}$-saturated seawater evenly distributed in the water column, as described by Riebesell et al. (2013). $\mathrm{CO}_{2}$ additions were carried out in the afternoons of $t 0-t 4$, so as to not interfere with the daily sampling. $\mathrm{A} \mathrm{CO}_{2}$ addition was also made in the upper $7 \mathrm{~m}$ on $t 15$ to counter strong outgassing in the upper water column. Initial $f \mathrm{CO}_{2}$ ranged from $\sim 240 \mu \mathrm{atm}$ in the two ambient control mesocosms to up to $1650 \mu \mathrm{atm}$ (Fig. 1a). Unenriched filtered $(50 \mu \mathrm{m})$ seawater was added to the two control mesocosms (M1, M5). The seawater used for the additions to the mesocosms was collected from the Tvärminne Storfjärden from a depth of $10 \mathrm{~m}$ by a pipe connected to the laboratory at the research station.

Depth-integrating water samplers (IWS, HYDRO-BIOS, Kiel) were used to collect water from 0 to $17 \mathrm{~m}$ depth in each mesocosm for analysis of particulate matter, dissolved inorganic and organic matter, phytoplankton pigments, phytoplankton abundances and carbonate chemistry variables. Samples of carbonate chemistry variables were taken directly from the IWS on board the sampling boat, whereas all other samples were pooled in $10 \mathrm{~L}$ plastic carboys and stored on board in the dark until subsampling onshore (Paul et al., 2015). Particulate matter collected in the sediment trap was pumped to the surface and collected in sampling bottles (Boxhammer et al., 2016).

Particulate matter $(\mathrm{C}, \mathrm{N}, \mathrm{P})$ and phytoplankton pigment samples were collected onto GF/F filters (nominal pore size of $0.7 \mu \mathrm{m}, 25 \mathrm{~mm}$ diameter, Whatman) by gentle vacuum filtration (pressure $<200$ mbar). Filters and glass Petri dishes were combusted at $450{ }^{\circ} \mathrm{C}$ for $6 \mathrm{~h}$ before use. Collected particulate sediment material was concentrated, freeze-dried and ground to a homogenous powder, while supernatant subsamples were filtered and subsequently analysed as for water column material. Total particulate carbon and nitrogen (TPC and PON) content and isotopic composition were analysed according to Sharp (1974) using an elemental analyser (EuroEA) coupled by either a Conflo II to a Finnigan 
Delta ${ }^{\text {Plus }}$ isotope ratio mass spectrometer or by a Conflo III to a Thermo Finnigan Delta ${ }^{\text {Plus }}$ XP isotope ratio mass spectrometer. Stable N isotope composition of particulate $\mathrm{N}$ is reported in permil $(\% \circ)$ relative to the atmospheric $\mathrm{N}_{2}$ standard (AIR). Total particulate phosphorus concentrations were determined spectrophotometrically following sample digestion as described in Hansen and Koroleff (1999). Samples for biogenic silica (BSi) analyses were collected on cellulose acetate filters (pore size of $0.65 \mu \mathrm{m}, 25 \mathrm{~mm}$ diameter, Whatman) by filtration as described above for particulate matter. Concentrations were determined spectrophotometrically following sample digestion according to Hansen and Koroleff (1999). Samples for determination of nanomolar concentrations of dissolved inorganic nutrients were filtered (GF/F, nominal pore size of $0.7 \mu \mathrm{m}$, Fisher Scientific). Nitrate and nitrite (hereafter nitrate) and dissolved inorganic phosphate concentrations were then analysed colorimetrically using a $2 \mathrm{~m}$ liquid waveguide capillary cell (Patey et al., 2008; Zhang and Chi, 2002) and a miniaturised detector (Ocean Optics Ltd). Concentrations of ammonium $\left(\mathrm{NH}_{4}^{+}\right)$were determined fluorimetrically (Trilogy, Turner) according to Kérouel and Aminot (1997). Total dissolved nitrogen (TDN) was analysed using a high-temperature catalytic combustion technique with a Shimadzu TOC-TN V analyser as described by Badr et al. (2003). Samples were filtered (GF/F, nominal pore size of $0.7 \mu \mathrm{m}$, Fisher Scientific) to remove particulate material and collected in clean glass vials, acidified with $\mathrm{HCl}$ to $\mathrm{pH} 1.9$ and flame-sealed. Filters and vials were combusted for $6 \mathrm{~h}$ at $450{ }^{\circ} \mathrm{C}$ before use. Dissolved organic nitrogen (DON) concentrations were calculated by subtracting the inorganic $\mathrm{N}$ concentrations from TDN. Phytoplankton pigments were extracted in acetone $(90 \%)$ and after homogenisation and centrifugation, the supernatant was filtered $(0.2 \mu \mathrm{m}$ PTFE filters, VWR International) and concentrations were determined by reverse phase high-performance liquid chromatography (HPLC; WATERS HPLC with a Varian Microsorb-MV 100-3 C8 column; Barlow et al. (1997), Derenbach et al., 1969). A library of pre-measured commercial standards was used to calibrate peaks.

Phosphate excess (P*, Deutsch et al., 2007) was calculated from the dissolved inorganic phosphate, nitrate and ammonium concentrations according to

$\mathrm{P}^{*}=\left[\mathrm{PO}_{4}^{3-}\right]-\frac{\left[\mathrm{NO}_{3}^{-}\right]+\left[\mathrm{NH}_{4}^{+}\right]}{16}$.

Dissolved silicate (DSi) drawdown was calculated as the difference in DSi concentration on a given sampling day $(t x)$ and $t 1$ :

DSi drawdown $=[\mathrm{DSi}]_{t 1}-[\mathrm{DSi}]_{t x}$.

A comprehensive description of mesocosm deployment, setup and sampling procedures including sample collection, handling and analyses for particulate matter, dissolved inorganic and organic matter, phytoplankton pigments and sediment trap particulate matter is covered in Paul et al. (2015),
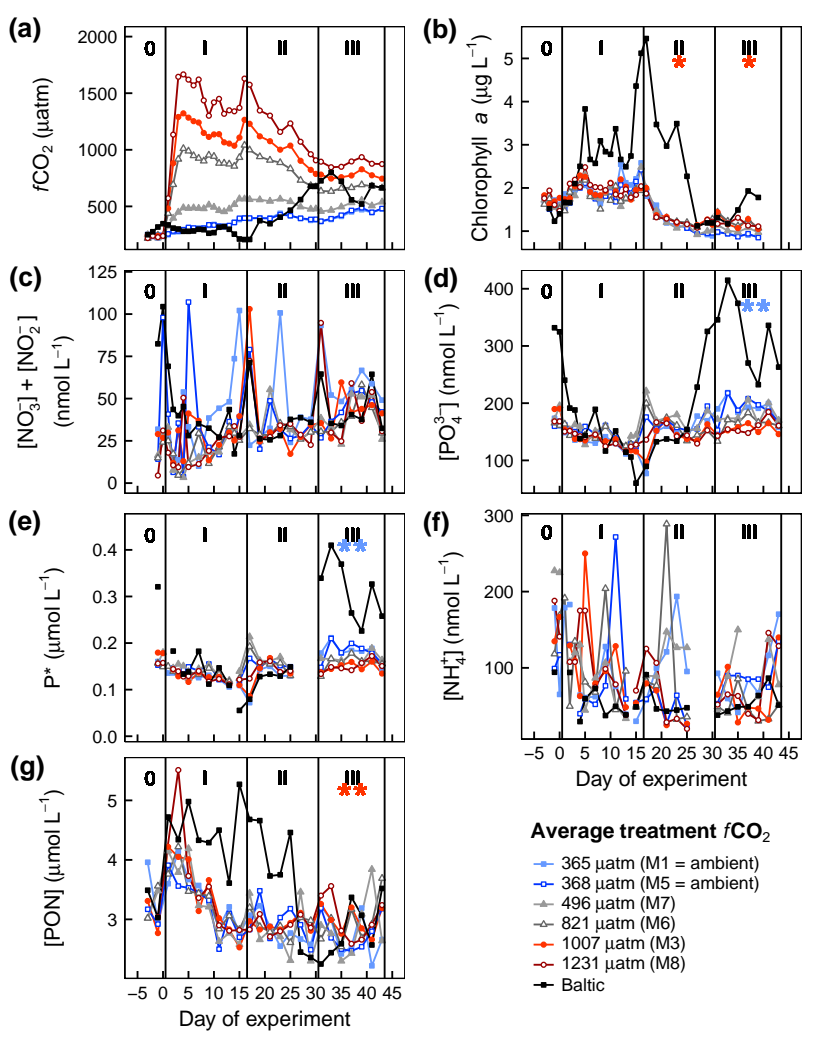

Day of experiment

Average treatment $f \mathrm{CO}_{2}$

- $365 \mu$ atm (M1 = ambient) -368 нatm (M5 = ambient) $-496 \mu$ atm (M7)
$-\quad 821$ (Matm (M6)

$\rightarrow 1007 \mu \mathrm{atm}(\mathrm{M} 3)$

$\rightarrow-1231 \mu \mathrm{atm}(\mathrm{M} 8)$

$\rightarrow$ Baltic

Figure 1. Temporal development in (a) calculated $f \mathrm{CO}_{2}$ using measured dissolved inorganic carbon (DIC) and $\mathrm{pH}_{T}$, (b) chlorophyll $a$ concentrations, (c) dissolved inorganic nitrate concentrations, (d) dissolved inorganic phosphate concentrations over the study period, (e) excess dissolved inorganic phosphate concentrations $\left(\mathrm{P}^{*}\right)$ calculated according to Eq. (1), (f) measured dissolved ammonium concentrations and (g) suspended particulate organic nitrogen concentrations. Data for (a-d), and (f-g) are from Paul et al. (2015). $*=p<0.05, * *=p<0.01$, where red indicates positive and blue a negative detected effect of $f \mathrm{CO}_{2}$. Average treatment $f \mathrm{CO}_{2}$ was calculated for each mesocosm between $t 1$ and $t 43$.

also in this Special Issue. An overview table of sampled variables for the entire experiment, including sampling frequency, is also presented in this accompanying manuscript.

\section{$2.2 \quad \mathrm{~N}_{2}$-fixation rate incubations}

Incubations for determination of $\mathrm{N}_{2}$-fixation rates were carried out using an approach described by Mohr et al. (2010), with some modifications for the preparation of the ${ }^{15} \mathrm{~N}$ $\mathrm{N}_{2}$ enriched seawater. Seawater used for ${ }^{15} \mathrm{~N}-\mathrm{N}_{2}$ enrichments was filtered (polycarbonate Isopore ${ }^{\mathrm{TM}}$ filter, pore size of $0.22 \mu \mathrm{m}, 47 \mathrm{~mm}$ diameter) before being pumped through a degassing membrane (Membrana Mini Module G542) attached to a water-jet pump to remove ambient $\mathrm{N}_{2}$. The degassing system was cleaned with $5 \% \mathrm{HCl}$ before and after use, followed by cycling with deionised water (MilliQ, Millipore) to remove any traces of acid. Seawater from the Tvär- 
minne Storfjärden was collected from a depth of $10 \mathrm{~m}$ and cycled once through the degassing system before collection in an air-tight, acid-cleaned bag with septum (SKC Tedlar ${ }^{\text {TM }}$ Bag with single polypropylene fitting) without exposure to the atmosphere. $1 \mathrm{~mL}$ of ${ }^{15} \mathrm{~N}-\mathrm{N}_{2}$ gas (98 atom $\%{ }^{15} \mathrm{~N}$, Sigma Aldrich, lot no.: CX0937 until $t 21$, SZ1670V after $t 21$ ) was injected through the septum into the bag for every $100 \mathrm{~mL}$ of sample. The resulting bubble was dissolved and the ${ }^{15} \mathrm{~N}-\mathrm{N}_{2}-$ enriched seawater was stored at the in situ temperature of the mesocosms until addition to incubation bottles. Seawater for the blank incubations was prepared in a separate bag using the same process; however ambient air was added instead of isotopically labelled ${ }^{15} \mathrm{~N}-\mathrm{N}_{2}$ gas.

Water samples for $\mathrm{N}_{2}$-fixation rate incubations were directly transferred in a gentle manner from the integrating water sampler into $2.3 \mathrm{~L}$ polycarbonate bottles on board the sampling boat using silicon tubing. The bottles were stored in a closed cool box to control temperature and to block sunlight until return to the onshore laboratory. Each bottle was weighed and homogenised by gentle rotation before $70-90 \mathrm{~mL}$ of water was removed to make space for the ${ }^{15} \mathrm{~N}$-enriched seawater. Enriched or "blank" seawater was transferred from the Tedlar ${ }^{\mathrm{TM}}$ bags to the respective bottles through Tygon ${ }^{\mathrm{TM}}$ tubing, immersed in the sample bottle, using a peristaltic pump to minimise tracer loss through exposure to atmosphere. Incubation bottles were filled with no headspace. After addition, the caps were immediately screwed on to seal the bottles air tight. During these procedures, the bottles were reweighed at each step in order to determine the exact amount of isotope label inside each bottle. The final ${ }^{15} \mathrm{~N}$ enrichment of dissolved $\mathrm{N}_{2}$ gas in each bottle was between 1.0 and 3.5 atom \%. The bottles were then mixed by gentle rotation and placed in a climate chamber at in situ temperature and under controlled light conditions $\left(\sim 73 \pm 1 \mu \mathrm{mol}\right.$ photons $\mathrm{m}^{-2} \mathrm{~s}^{-1}$, mean $\pm \mathrm{SD}$ (standard deviation)). Irradiance was measured using a LI-COR LI-192 quantum sensor. Measured irradiance was within the range of average depth-integrated $(0-17 \mathrm{~m})$ irradiance in the mesocosms taken from daily CTD (Conductivity Temperature Depth probe) profiles between 13:30 and 14:30 LT (20 to $300 \mu \mathrm{mol}$ photons $\mathrm{m}^{-2} \mathrm{~s}^{-1}$ ). The light-dark cycle followed the natural sunrise-sunset variation which on the summer solstice (21 June 2012, $t-1)$ was $19: 5 \mathrm{~h}(L: D)$. Climate chamber temperature was programmed to follow the daily integrated water column temperature as recorded by the afternoon CTD sampling, and thus is reported as in situ temperature. Consistency between irradiance conditions at each bottle position was achieved by a rotation regime. Bottles were rotated gently to mix and the bottle position rotated systematically approximately every $3 \mathrm{~h}$ during the light cycle. Time of rotation was recorded, allowing the calculation of average irradiance between each individual bottle.

Incubations were terminated after $24 \mathrm{~h}$ by filtration through a combusted $\left(6 \mathrm{~h}\right.$ at $\left.450^{\circ} \mathrm{C}\right)$ and acid rinsed $(1 \%$ $\mathrm{HCl}) \mathrm{GF} / \mathrm{F}$ filter $(0.7 \mu \mathrm{m}$ pore size, $25 \mathrm{~mm}$ diameter, What- man) under reduced vacuum ( $<200 \mathrm{mbar})$. Filters were placed in glass Petri dishes (combusted $6 \mathrm{~h}, 450{ }^{\circ} \mathrm{C}$ ), frozen immediately and stored at $-20^{\circ} \mathrm{C}$ until analysis on a mass spectrometer as described for particulate $\mathrm{C}$ and $\mathrm{N}$ analyses above and also in Paul et al. (2015). Rates were calculated according to Montoya et al. (1996). Estimated internal analytical uncertainty in calculated $\mathrm{N}_{2}$-fixation rates was less than $\pm 10 \%$ when rates were above the detection limit. The detection limit was determined as a difference in $\delta^{15} \mathrm{~N}$ between initial and final values of larger than $1.0 \%$. This corresponded to a calculated rate of more than $0.15 \mathrm{nmol} \mathrm{N} \mathrm{L}^{-1} \mathrm{day}^{-1}$.

\subsection{Phytoplankton counts}

Counts of phytoplankton cells $>20 \mu \mathrm{m}$ were made from $50 \mathrm{~mL}$ samples fixed with acidic Lugol's iodine solution ( $1 \%$ final concentration). Samples were concentrated using gravitational settling and counted under an inverted microscope (ZEISS Axiovert 100) after Utermöhl (1958) and following the guidelines for determination of phytoplankton species composition, abundance and biomass for the COMBINE programme provided by HELCOM (Annex C-6). The cells were counted either on half of the chamber at 100 -fold or on three to four strips at 200 -fold magnification. Filamentous cyanobacteria were counted in $50 \mu \mathrm{m}$ length units. Plankton were identified where possible to the species level according to Hoppenrath et al. (2009), Kraberg et al. (2010) and Tomas (1997). Biovolumes of counted plankton cells were calculated according to Olenina et al. (2006) and converted to cellular organic carbon quotas by the equations of MendenDeuer and Lessard (2000).

\subsection{Statistical analyses}

A linear regression analysis was applied to determine the relationship between mean $f \mathrm{CO}_{2}$ and the mean response of each variable for the three experimental phases (Phase I, II and III), as described in Paul et al. (2015). Linear regression analyses were undertaken using R software (R Core Team, 2015).

\section{Results}

Three experimental phases after initial $\mathrm{CO}_{2}$ manipulation on $t 0$ were defined in Paul et al. (2015) using temperature and chlorophyll a (Chl $a$ ) fluctuations: Phase I $(t 1-t 16)$, Phase II $(t 17-t 30)$ and Phase III $(t 31-t 43)$. These phases are also used to assist with data interpretation in this manuscript. Reported average $f \mathrm{CO}_{2}$ was calculated for each mesocosm between $t 1$ and $t 43$. 


\subsection{Inorganic nutrient availability and nutrient limitation}

There were low concentrations of inorganic $\mathrm{N}$ present throughout the study period, with inorganic nitrate concentrations in the range of $3-107 \mathrm{nmol} \mathrm{L}^{-1}$ (Fig. 1c). Ammonium was the dominant source of inorganic $\mathrm{N}$, with concentrations ranging between 20 and $289 \mathrm{nmol} \mathrm{L}^{-1}$. Hence $\mathrm{NH}_{4}^{+}$ was also included in the calculations of $\mathrm{P}^{*}$ (excess phosphate) and inorganic nutrient elemental stoichiometry according to the Redfield ratio (Fig. 1e, Eq. 1).

There was an excess of inorganic phosphate to inorganic $\mathrm{N}$ in all mesocosms $\left(\mathrm{P}^{*}>0 \mathrm{nmol} \mathrm{L}^{-1}\right.$, Fig. 1e) and the surrounding waters throughout the study period, with phosphate concentrations ranging between 72 and $214 \mathrm{nmol} \mathrm{L}^{-1}$ in the mesocosms and up to $410 \mathrm{nmol} \mathrm{L}^{-1}$ outside the mesocosms in the surrounding Archipelago Sea. Inorganic phosphate concentrations decreased during Phase I, followed by an increase at the beginning of Phase II. Concentrations in the ambient/control treatments remained higher than in the higher $\mathrm{CO}_{2}$ treatments in Phase III. Nitrate concentrations increased slightly throughout the experiment, whereas $\mathrm{NH}_{4}^{+}$concentrations were variable. Samples for $\mathrm{NH}_{4}^{+}$analyses were lost on $t 27$ and $t 29$. There did not appear to be any remarkable relationship linking accumulated precipitation (between sampling days) and the increase in nitrate, indicating that wet atmospheric deposition of nitrate into the mesocosms was effectively prevented by the mesocosm roofs and did not affect the nitrate pool. Precipitation data for the Hanko weather station (ID no.: GHCND:FIE00142025, latitude: 59.8439, longitude: 23.2517) were obtained from the National Oceanographic Data Center (NOAA).

\subsection{Diatom abundance, silicate dynamics and dissolved N utilisation}

Diatoms were mostly abundant at the beginning of the experiment, with the species Chaetoceros sp. and Skeletonema marinoi present in the large size class $(>20 \mu \mathrm{m}$, Fig. 2). Fucoxanthin marker pigment concentrations in this size class and suspended BSi concentrations $(>0.65 \mu \mathrm{m})$ declined markedly during the first few days in Phase I and the dynamics fitted well to the microscopy counts of both Chaetoceros sp. and Skeletonema marinoi. Dissolved silicate (DSi) concentrations continued to decrease up until $t 13$. No statistically significant difference between $\mathrm{CO}_{2}$ treatments was detected for diatom abundance (microscopy counts), DSi drawdown or BSi concentrations (Table 1, Fig. 2c, e), apart from BSi in Phase II where a positive effect was detected ( $p=0.034$, see Paul et al. (2015) for statistical analyses).

Dissolved organic nitrogen (DON) concentrations ranged between 20 and $25 \mu \mathrm{mol} \mathrm{L}^{-1}$ (Fig. 2a). DON concentrations appeared to decrease during Phase I; however considerable variability in the data meant this DON drawdown could not be accurately quantified. (a)
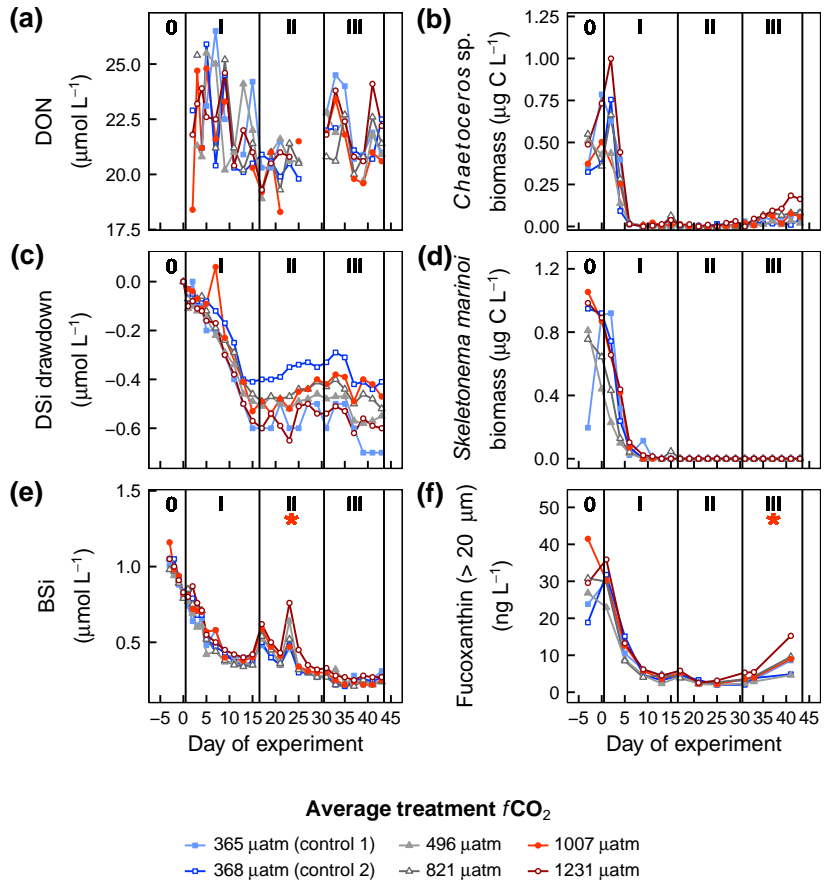

Figure 2. Temporal development in (a) dissolved organic nitrogen concentrations (DON), (c) dissolved silicate (DSi) drawdown and (e) particulate biogenic silicate (BSi) concentrations (data from Paul et al., 2015), the abundances of the two dominant diatom species determined by microscopy (b, d) and (f), Fucoxanthin marker pigment concentrations $(>20 \mu \mathrm{m})$, a key pigment in diatoms. The red asterisk denotes significant positive effect of $\mathrm{CO}_{2}(*=p<0.05)$.

\subsection{Diazotroph abundance and $\mathrm{N}_{2}$-fixation rates, $\delta^{15} \mathrm{~N}$ in particulate $\mathbf{N}$}

The abundance of filamentous diazotrophic cyanobacteria remained low throughout the experiment, with no significant bloom development $\left(<6 \mu \mathrm{g} \mathrm{C} \mathrm{L}{ }^{-1}\right.$, Fig. 3a). The most dominant species, A. flos-aquae, had a maximum biomass of $4.9 \mu \mathrm{g} \mathrm{L} \mathrm{L}^{-1}$ in the mesocosms (M1, t27), whereas the next most abundant species, Anabaena sp., had a maximum biomass in the water column of $0.18 \mu \mathrm{g} \mathrm{CL}^{-1}$ (M1, $t 17$ ). Aphanizophyll, a pigment present in A. flos-aquae and Anabaena sp. (Schluter et al., 2004), was detected in both suspended material in the water column $(>20 \mu \mathrm{m})$ and in the sinking material collected in the sediment trap. Concentrations of this pigment increased at the end of Phase I, concurrent with an increase in $\mathrm{N}_{2}$-fixation rates (Fig. 3). Although numbers in the mesocosms remained generally low, A. flos-aquae abundances, based on microscopy counts and phytoplankton pigment analyses, were highest in Phase II/III and lowest in Phase I (Fig. 3). A. flos-aquae biomass outside the mesocosms was up to $30 \mu \mathrm{g} \mathrm{L}^{-1}$ on $t 15$ and is supported by high Aphanizophyll pigment concentrations of $109 \mathrm{ng}$ (mg TPC) ${ }^{-1}$ also on $t 15$ (data not shown). 
Table 1. Summary of linear regression analyses of $f \mathrm{CO}_{2}$ and nutrient stoichiometry, dissolved silicate drawdown, abundance of large $(>20 \mu \mathrm{m})$ dominant diatom species present (Chaetoceros sp., Skeletonema marinoi), $\mathrm{N}_{2}$-fixation rates, stable nitrogen isotope natural abundance and particulate biogenic silica and particulate organic nitrogen concentrations. Numbers in bold indicate that the variable had a negative correlation with average $f \mathrm{CO}_{2}$. Dashes indicate no regression was completed to avoid any bias in the conclusions because either no data are available, or no complete data set is available. The asterisk (*) indicates data and statistical analyses from Paul et al. (2015). Degrees of freedom, $n=4$.

\begin{tabular}{|c|c|c|c|c|}
\hline Variable & Phase & $p$ & $F$-statistic & $R^{2}$ \\
\hline \multirow[t]{3}{*}{$\mathrm{N}_{2}$-fixation rate } & I & 0.764 & 0.104 & 0.025 \\
\hline & II & - & - & - \\
\hline & III & - & - & - \\
\hline \multirow[t]{3}{*}{$\delta^{15} \mathrm{~N}$ in suspended particulate matter } & I & 0.417 & 0.819 & 0.170 \\
\hline & II & - & - & - \\
\hline & III & - & - & - \\
\hline \multirow[t]{3}{*}{$\delta^{15} \mathrm{~N}$ in sinking particulate matter } & I & 0.289 & 1.494 & 0.272 \\
\hline & II & - & - & - \\
\hline & III & - & - & - \\
\hline \multirow[t]{3}{*}{ DSi drawdown } & I & 0.927 & 0.010 & 0.002 \\
\hline & II & 0.520 & 0.496 & 0.110 \\
\hline & III & 0.966 & 0.001 & 0.002 \\
\hline \multirow[t]{3}{*}{ Chaetoceros sp. abundance } & I & 0.737 & 0.129 & 0.031 \\
\hline & II & - & - & - \\
\hline & III & 0.075 & 5.726 & 0.589 \\
\hline \multirow[t]{3}{*}{ Skeletonema marinoi abundance } & I & 0.772 & 0.097 & 0.024 \\
\hline & II & - & - & - \\
\hline & III & - & - & - \\
\hline \multirow[t]{3}{*}{ Excess phosphate $\left(\mathrm{P}^{*}\right)$} & I & 0.493 & 0.569 & 0.125 \\
\hline & II & 0.783 & 0.086 & 0.021 \\
\hline & III & 0.004 & 37.560 & 0.904 \\
\hline \multirow[t]{3}{*}{ DIN : DIP (includes $\mathrm{NH}_{4}^{+}$) } & I & 0.647 & 0.569 & 0.125 \\
\hline & II & 0.556 & 0.412 & 0.093 \\
\hline & III & 0.797 & 0.076 & 0.019 \\
\hline \multirow[t]{3}{*}{ Biogenic silica $(\mathrm{BSi}) *$} & I & 0.070 & 0.601 & 6.032 \\
\hline & II & 0.034 & 0.717 & 10.120 \\
\hline & III & 0.553 & 0.095 & 0.419 \\
\hline \multirow[t]{3}{*}{ PON (total) * } & I & 0.668 & 0.051 & 0.214 \\
\hline & II & 0.490 & 0.126 & 0.576 \\
\hline & III & 0.001 & 0.940 & 62.890 \\
\hline
\end{tabular}

Rates of $\mathrm{N}_{2}$-fixation until $t 21$ ranged from below the detection limit at the beginning of the experiment, up to $4.4 \mathrm{nmolN} \mathrm{L}^{-1}$ day $^{-1}$ inside the mesocosms and up to $37.9 \mathrm{nmol} \mathrm{L}^{-1}$ day $^{-1}$ in the waters outside. We observed a substantial increase in the $\mathrm{N}_{2}$-fixation rates from 2.6 to $4.4 \mathrm{nmol} \mathrm{L}^{-1}$ day $^{-1}$ up to 50 to $60 \mathrm{nmol} \mathrm{L}^{-1}$ day $^{-1}$ between $t 21$ and $t 23$ without any remarkable change in diazotroph abundance of the same magnitude (Fig. 3). This was also evident in A. flos-aquae biomass-related $\mathrm{N}_{2}$-fixation rates (see Fig. B, Supplement). This increase coincided with the use of a new ${ }^{15} \mathrm{~N}-\mathrm{N}_{2}$ gas bottle with a lot number which was reported 2 years later as contaminated with ${ }^{15} \mathrm{~N}$-labelled $\mathrm{NH}_{4}^{+}$ and $\mathrm{NO}_{3}^{-}$by Dabundo et al. (2014) (Sigma Aldrich, lot no. SZ1670V). The measured rates from $t 23$ on are therefore not exclusively $\mathrm{N}_{2}$ fixation and are not reliable; thus they were excluded from analyses. In addition to the bottle assays, the ${ }^{15} \mathrm{~N}-\mathrm{N}_{2}$ isotope tracer was also added directly to all mesocosms except for M1 (control) and M7 (see Supplement). Therefore these two mesocosms were not affected by this contamination issue. Hence, the natural abundance $\delta^{15} \mathrm{~N}$ data from the suspended material in the water column and the sinking material from the sediment trap are reported for the entire experiment ( $t-3$ until $t 43$ ) for M1 and M7 mesocosms (Fig. 3e, f) but only until $t 21$ for M3, M5, M6 and 

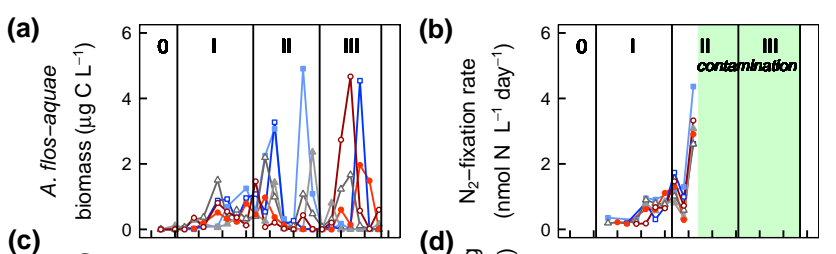

(c)

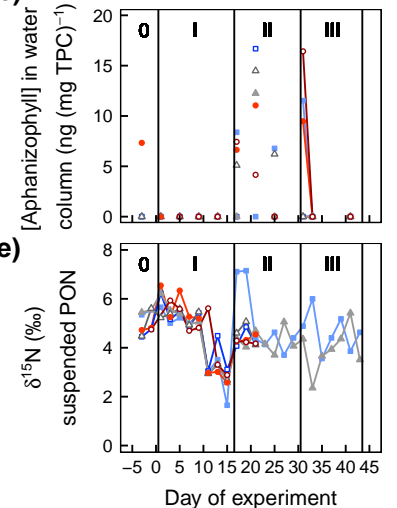

(d)

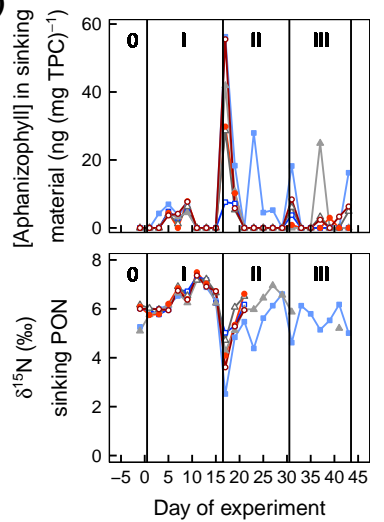

$$
\begin{aligned}
& \text { Average treatment } f \mathrm{CO}_{2} \\
& -365 \mu \mathrm{atm} \text { (control 1) } \rightarrow 496 \mu \mathrm{atm} \rightarrow 1007 \mu \mathrm{atm} \\
& \rightarrow 368 \mu \mathrm{atm} \text { (control 2) } \rightarrow-\triangleleft 21 \mu \mathrm{atm} \quad \rightarrow 1231 \mu \mathrm{atm}
\end{aligned}
$$

Figure 3. Variables indicating abundance and activity of filamentous diazotrophic cyanobacteria: (a) biomass of A. flos-aquae calculated from microscopy abundance data, (b) $\mathrm{N}_{2}$-fixation rates determined by stable isotope incubations, (c) carbon-normalised Aphanizophyll marker pigment concentration $(>20 \mu \mathrm{m})$ relative as a proxy for A. flos-aquae abundance in the water column and (d) in the sediment trap material, (e) natural abundance $\delta^{15} \mathrm{~N}$ of particulate organic nitrogen (PON) in the water column and (f) natural abundance $\delta^{15} \mathrm{~N}$ in the sinking particle organic nitrogen collected in the sediment trap determined by analyses on an isotope ratio mass spectrometer. The green shaded area in (b) between $t 23$ and $t 43$ indicates when contaminated ${ }^{15} \mathrm{~N}-\mathrm{N}_{2}$ gas was used in incubations (see Dabundo et al., 2014).

M8. Any $\mathrm{NH}_{4}^{+}$or nitrate added to the four mesocosms with the isotope tracer was highly isotopically enriched in ${ }^{15} \mathrm{~N}$ but was in very low concentration and so was insignificant for the nutrient budget.

The natural abundance $\delta^{15} \mathrm{~N}$ in suspended particulate $\mathrm{N}$ in the mesocosms decreased during the period of higher $\mathrm{Chl} a$ in Phase I from $6.0 \pm 0.5 \%$ on $t 1$ to $2.6 \pm 0.5 \%$ on $t 15$ (mean $\pm \mathrm{SD}$ ), before increasing on $t 17$. No other remarkable fluctuations were observed, including the period after t21 in M1 and M7 (Fig. 3e). A decrease in $\delta^{15} \mathrm{~N}$ in particulate $\mathrm{N}$ may indicate potential input of atmospheric $\mathrm{N}$ with a low $\delta^{15} \mathrm{~N}$ into particulate matter via $\mathrm{N}_{2}$-fixation during this period or potential uptake of ammonium with a $\delta^{15} \mathrm{~N}$ signature depleted through ammonification. This relationship between measured $\mathrm{N}_{2}$-fixation rates and $\delta^{15} \mathrm{~N}$ in suspended particulate $\mathrm{N}$ fits well during Phase I; however it breaks down from Phase II onwards, indicating that newly fixed $\mathrm{N}$ was a very minor component of the PON pool, with little influence on $\delta^{15} \mathrm{~N}$. A sharp decrease in $\delta^{15} \mathrm{~N}$ in the sinking

particulate material occurred on $t 17$, the same day that considerable amounts of Aphanizophyll and Fucoxanthin were found in the sediment trap material (Fig. 3d, f, Fucoxanthin not shown). This was 1 day after the mesocosm walls were cleaned, indicating that there were likely diazotrophic species and diatoms attached to the mesocosm walls. Identification from microscope photos revealed the presence of filamentous cyanobacteria with heterocysts in the collected sediment trap material.

Assessment of in situ $\mathrm{N}_{2}$-fixation rates based on ${ }^{15} \mathrm{~N}$ uptake from the combined dissolved $\mathrm{N}$ pool of $\mathrm{NO}_{3}^{-}, \mathrm{NH}_{4}^{+}$and $\mathrm{N}_{2}$ was abandoned due to high uncertainty in initial ${ }^{15} \mathrm{~N}$ enrichment and concentrations of the combined dissolved $\mathrm{N}$ pool, and fast saturation of label uptake after ca. 4 days (2 successive sampling days). To assess the contribution of diazotrophy to $\mathrm{N}$ supply in the mesocosms, we calculated a theoretical cumulative diazotrophic $\mathrm{N}$ input using measured $\mathrm{N}_{2}$-fixation rates from bioassays up until $t 21$ (M1 = $20 \mathrm{nmol} \mathrm{NL}^{-1}$ ), and then assumed a constant $\mathrm{N}_{2}$-fixation rate of $4 \mathrm{nmol} \mathrm{NL}^{-1}$ day $^{-1}$ into particulate $\mathrm{N}$ between $t 23$ and $t 43$ (total $=80 \mathrm{nmolN} \mathrm{L}^{-1}$ ). The assessment for between $t 23$ and $t 43$ is based on the premise of continued elevated A. flos-aquae biomass and assuming $50 \%$ exudation of fixed $\mathrm{N}$ as DON or $\mathrm{NH}_{4}^{+}\left(<t 21=20 \mathrm{nmol} \mathrm{N} \mathrm{L}^{-1}\right.$, $>t 21=80 \mathrm{nmol} \mathrm{L}^{-1}$, total $\left.=100 \mathrm{nmol} \mathrm{NL}^{-1}\right)$, and lies within the range of TDN release estimates from the literature for filamentous diazotrophic cyanobacteria in the Baltic Sea (33-80\%, Ohlendieck et al., 2007; Ploug et al., 2010; Stal et al., 2003; Wannicke et al., 2013). This yielded a theoretical new $\mathrm{N}$ input from A. flos-aquae of only $200 \mathrm{nmolNL}^{-1}$, amounting to $\sim 5 \%$ of mean PON pool standing stock $\left(\sim 3 \mu \mathrm{mol} \mathrm{L} \mathrm{L}^{-1}\right)$ and is clearly at the higher end of estimations. We calculated corresponding $\mathrm{N}$ requirement of the plankton community of $27.2 \mathrm{nmol} \mathrm{N} \mathrm{L}^{-1}$ day $^{-1}$ from the average phosphorus uptake rate across all treatments of $1.7 \mathrm{nmol} \mathrm{PO}_{4}^{3-} \mathrm{L}^{-1}$ day $^{-1}$ from $t 1-t 30$ as reported by Nausch et al. (2016), by assuming Redfield nutrient uptake stoichiometry $(16 \mathrm{~N}: 1 \mathrm{P})$. This is almost 7 times larger than estimated daily diazotrophic $\mathrm{N}$ inputs of $\sim 4 \mathrm{nmol} \mathrm{N} \mathrm{L}^{-1}$ day $^{-1}$, corresponding to $14 \%$ of calculated community $\mathrm{N}$ requirement.

Low filamentous diazotrophic cyanobacteria abundances exacerbated the inherent sampling error in both microscopy and pigment analyses due to patchy distribution and the tendency of filaments to aggregate. Hence, unfortunately no reliable statistical analyses on the effect of higher $f \mathrm{CO}_{2}$ on diazotroph abundance or marker pigment concentration could be undertaken, for any phase of the experiment. Any potential $\mathrm{CO}_{2}$ effect on diazotroph abundance was also not obvious on visual data inspection, and no effect could be detected on $\mathrm{N}_{2}$-fixation rates or $\delta^{15} \mathrm{~N}$ natural abundance in suspended particulate matter from the water column or sediment trap particulate matter up until $t 21$ (Table 1 ), when rates were re- 
liable and there were data from a sufficient number of $\mathrm{CO}_{2}$ treatments.

\section{Discussion}

\subsection{Effects of elevated $\mathrm{CO}_{2}$ on diazotrophic $\mathrm{N}$ inputs}

Bioavailable $\mathrm{N}$ was present in low concentrations and was probably the limiting macronutrient in the plankton community. Hence, higher phytoplankton biomass and lower phosphate concentrations at higher $\mathrm{CO}_{2}$ observed in this same mesocosm study (Paul et al., 2015), may have suggested relief of $\mathrm{N}$ limited growth by potentially increased $\mathrm{N}_{2}$ fixation. However we have no strong evidence to support this hypothesis based on $\mathrm{N}$ pool standing stocks and estimated diazotrophic $\mathrm{N}$ inputs. The only statistically significant, but very minor, correlation was a positive relationship between $\mathrm{CO}_{2}$ and PON concentrations (Fig. 1g, Table 1, $0.08 \mu \mathrm{mol}$ $\mathrm{L}^{-1}, 3 \%$ difference in PON, slope $=1.75 \times 10^{-4} \mu \mathrm{mol} \mathrm{L}{ }^{-1}$ $\mu \mathrm{atm}^{-1}$, data from Paul et al., 2015). No significant difference in $\mathrm{N}_{2}$-fixation rates (until $t 21$ ) or A. flos-aquae abundance at elevated $\mathrm{CO}_{2}$ compared to the ambient treatments was detected (Table 1, Fig. 3). Phosphate turnover rates, a potential indicator of $\mathrm{P}$ demand for $\mathrm{N}_{2}$ fixation, were also unaffected by $\mathrm{CO}_{2}$ in Phase I or Phase II (Nausch et al., 2016). These variables $\left(\mathrm{N}_{2}\right.$ fixation and phosphate uptake rates) provide a more sensitive measure of turnover rates of $\mathrm{N}$ and $\mathrm{P}$ than assessing changes in $\mathrm{N}$ pool standing stocks in this tightly coupled regenerative plankton community. Unfortunately, we only have reliable $\mathrm{N}_{2}$-fixation rates from incubations until $t 21$ due to contamination of ${ }^{15} \mathrm{~N}-\mathrm{N}_{2}$ gas with bioavailable $\mathrm{N}$ compounds (Dabundo et al., 2014) and not after $\sim t 25$ when significant $\mathrm{CO}_{2}$-related differences in $\mathrm{C}$ and $\mathrm{P}$ pools were apparent. Hence, in the later stages of the experiment (Phase II and III), it is possible that there was a divergence in $\mathrm{N}_{2}$-fixation rates between treatments that was missed, despite low abundances of A. flos-aquae, the dominant filamentous diazotrophic cyanobacterium present. Nonetheless we estimate that the contribution of diazotrophy to $\mathrm{N}$ supply in the mesocosms over the study duration of 43 days was small $\left(\sim 200 \mathrm{nmol} \mathrm{L}^{-1}\right)$. Maximum measured $\mathrm{N}_{2}$ fixation rates of $4.4 \mathrm{nmol} \mathrm{N} \mathrm{L}^{-1} \mathrm{day}^{-1}$ were low compared to reported for the Baltic Sea in midsummer, which range from 1.7 up to $550 \mathrm{nmol} \mathrm{N} \mathrm{L}^{-1}$ day $^{-1}$ (Farnelid et al., 2013; Ohlendieck et al., 2000, 2007; Wasmund et al., 2001). This is due to the rather low A. flos-aquae biomass in the mesocosms compared to literature values (this study: maximum biomass $=5 \mu \mathrm{g} \mathrm{CL} \mathrm{L}^{-1}$ integrated over $0-17 \mathrm{~m}$; Gulf of Finland: 22 $-26 \mu \mathrm{g} \mathrm{L}^{-1}$ in the surface $5 \mathrm{~m}, 6-7 \mu \mathrm{gCL}^{-1}$ at $20 \mathrm{~m}$ deep in July, Laamanen and Kuosa, 2005). Thus even if all newly fixed $\mathrm{N}$ by diazotrophs was transferred to diazotroph and plankton biomass (i.e. PON pool), this small accumulation would most likely remain below the detection limits in the suspended PON pool $\left(\sim 10 \%=0.3 \mu \mathrm{mol} \mathrm{L}^{-1}\right)$. Indica- tions from the stable $\delta^{15} \mathrm{~N}$ in suspended particulate $\mathrm{N}$ supports this small contribution of diazotrophs between $t 17$ and $t 21$ despite the observed increase in measured $\mathrm{N}_{2}$-fixation rates at this time. On top of this, any $\mathrm{CO}_{2}$-related differences in $\mathrm{N}_{2}$ fixation would be near impossible to resolve in this small contribution by diazotrophs.

The absence of any detectable effect may of course be influenced by the relatively low abundances of filamentous diazotrophic cyanobacteria in this study, as temperatures were mostly below temperatures thought to stimulate bloom development $\left(16^{\circ} \mathrm{C}\right.$, Wasmund et al. (1997); this study $8-16^{\circ} \mathrm{C}$, Paul et al., 2015). Nevertheless our results from this $\mathrm{CO}_{2}$ manipulation study are in agreement with studies from both the marine (Böttjer et al., 2014; Law et al., 2012) and freshwater (Shapiro, 1997; Yamamoto, 2009) realms which detected no significant effect of decreased $\mathrm{pH} /$ increased $\mathrm{CO}_{2}$ on diazotroph abundance and/or activity in natural plankton communities. These four independent studies all contradict physiological investigations in single-strain culture experiments where diazotroph growth and activity was modulated by $\mathrm{CO}_{2}$ availability (e.g. Barcelos e Ramos et al., 2007; Czerny et al., 2009; Eichner et al., 2014; Fu et al., 2008; Hutchins et al., 2013; Wannicke et al., 2012). Diazotrophic organisms typically have slower growth rates than other organisms. Hence any potential influence of ocean acidification on their physiology may take longer to become apparent in biogeochemical parameters sampled in larger scale field studies, where most sampled variables such as PON are a mixture of organic compounds of various origin and isotopic composition. In addition, the overall response to $\mathrm{CO}_{2}$ observed in such field studies is a combination of the pure physiological response, which can be observed in laboratory experiments, with trophic interactions such as grazing and competition between species for nutrients and light. However to the best of our knowledge, there are no direct $\mathrm{N}_{2}$-fixation rate measurements from $\mathrm{CO}_{2}$-manipulation studies with A. flos-aquae in the field which could shed light on any underlying physiological response of this diazotroph and confirm laboratory findings in the field. Furthermore, high grazing pressure, hence top-down control, particularly after $t 17$ (Lischka et al., 2015) may have overridden any potential $\mathrm{CO}_{2}$ effect of bottom-up control on diazotroph growth.

In addition to these highly visible filamentous $\mathrm{N}_{2}$ fixers, there is growing evidence to support the role of heterotrophic and non-phototrophic $\mathrm{N}_{2}$ fixation by smaller unicellular organisms in diverse ecosystems (Halm et al., 2012; Loescher et al., 2014; Moisander et al., 2010; Zehr et al., 2008) including in the Baltic Sea and Kattegat (Bentzon-Tilia et al., 2015; Farnelid et al., 2009), which cannot be quantified by common microscopic methods used in this experiment. Hence, while there appeared to be a good correlation between A. flos-aquae abundance and $\mathrm{N}_{2}$-fixation rates until $t 21$ in this study, we cannot rule out the contribution of heterotrophic organisms to the measured rates. However, regardless of the diazotroph community present, $\mathrm{N}_{2}$-fixation rates were low and diazotro- 
phy only made a small contribution $\left(<200 \mathrm{nmol} \mathrm{L}^{-1}\right)$ to the $\mathrm{N}$ cycle in this study. Thus we have no direct evidence from observations in this study that $\mathrm{N}_{2}$ fixation or diazotroph abundance (Fig. 3) were neither significantly influenced by $\mathrm{CO}_{2}$ nor that this could explain the observed higher particulate matter concentrations or lower phosphate concentrations in the higher $\mathrm{CO}_{2}$ treatments (Paul et al., 2015) based on hypothesised relief of $\mathrm{N}$ limitation.

In this area of the Baltic Sea, plankton communities, containing filamentous diazotrophic cyanobacteria, are exposed to large diurnal and seasonal changes in $\mathrm{pH}$ (Almén et al., 2014; Brutemark et al., 2011). In addition, filamentous cyanobacteria form characteristic surface aggregations. Inside these aggregations, microenvironments can create substantially different conditions compared to the surrounding water with large diurnal fluctuations in $\mathrm{pH}(7.4$ vs. 9.0) and $\mathrm{O}_{2}$ concentrations $\left(\sim 150-450 \mu \mathrm{mol} \mathrm{O}_{2} \mathrm{~L}^{-1}\right)$ and thus also inorganic carbon availability (Ploug, 2008). Hence natural exposure to highly variable carbonate chemistry conditions may have also played a role in dampening any potential influence of ocean acidification in this plankton community.

\subsection{Evidence from $\mathrm{N}$ pools of the importance of regenerative production and effects of $\mathrm{CO}_{2}$}

Productivity in this plankton community appeared to be dominated by regenerative production (sensu Dugdale and Goering, 1967) under low nitrate availability during Phase I, as has been observed in summer plankton communities in the Baltic Sea (Kuparinen, 1987; Sahlsten and Sörensson, 1989; Tamminen, 1995). DON appeared to be a more important $\mathrm{N}$ source than $\mathrm{N}$ derived from $\mathrm{N}_{2}$-fixation. Any relatively fresh and labile $\mathrm{N}$-rich dissolved organic matter (DOM) present after the decline of the spring bloom was likely remineralised by the bacterial community. Here, simultaneous drawdown of DSi and DON between $t-1$ and $t 15$ suggests that in particular diatoms, also persisting from the spring bloom, were beneficiaries of this organic $\mathrm{N}$ turnover. Available $\mathrm{NH}_{4}^{+}$ $\left(\sim 100 \mathrm{nmol} \mathrm{L}^{-1}\right)$ could not have supported the DSi uptake $\left(\sim 0.4 \mu \mathrm{mol} \mathrm{L}^{-1}\right)$ as the sole $\mathrm{N}$ source based on $\sim 1: 1$ molar $\mathrm{Si}: \mathrm{N}$ requirement by diatoms, thus suggesting instead potential rapid resupply of $\mathrm{NH}_{4}^{+}$through remineralisation of organic $\mathrm{N}$ by the heterotrophic community, particularly in Phase I and Phase II. Although there is no indication of a high level of $\mathrm{NH}_{4}^{+}$production above the variability in the data set, we presume this bioavailable $\mathrm{NH}_{4}^{+}$would have been very quickly assimilated into particulate $\mathrm{N}$ in the $\mathrm{N}$-limited plankton community. This rate of $\mathrm{N}$ regeneration probably limited net phytoplankton growth such that significant phytoplankton biomass could not accumulate in the water column. Nevertheless, neither the readily available $\mathrm{NH}_{4}^{+}$nor the nitrate pool were fully exploited by the plankton assemblage with up to $50 \mathrm{nmol} \mathrm{L}^{-1}$ of nitrate and $170 \mathrm{nmol} \mathrm{L}^{-1}$ of $\mathrm{NH}_{4}^{+}$remaining at the end of the study period on $t 43$. In fact, nitrate concentrations continually increased throughout the experi- ment at an average net rate of $1 \mathrm{nmol} \mathrm{NL}^{-1}$ day $^{-1}$ (Fig. 1c) despite proportionally high phosphate availability. This suggests a small net imbalance in $\mathrm{N}$ cycle processes and may be connected to ammonium inhibition of nitrate uptake during spring-bloom decline and post-bloom period in the study area (Tamminen, 1995), leading to this small accumulation of nitrate in the water column.

Neither a significant effect of $\mathrm{CO}_{2}$ was detected on the DON pool, nor DSi drawdown, or PON or BSi cumulative sinking fluxes (see also Paul et al., 2015 in this Special Issue). Likewise, if there was any difference in uptake of $\mathrm{N}$ from the $\mathrm{N}$-rich DOM pool (N:P $\sim 80: 1)$ between $\mathrm{CO}_{2}$ treatments, we could not detect the small signal $\left(\mathrm{nmol} \mathrm{L}^{-1}\right)$ outside of the analytical precision $(\mu \mathrm{mol} \mathrm{L}-1)$ of the DON measurements. Thus this organic $\mathrm{N}$ drawdown via regenerative production in diatoms in this study appeared to be either unaffected or immeasurable by simulated ocean acidification.

\section{Summary}

Plankton biomass build-up in this study was limited by low inorganic $\mathrm{N}$ availability; therefore organic $\mathrm{N}$ pools were utilised supporting regenerative production during the more productive period in Phase I, with diatoms benefitting from this $\mathrm{N}$ turnover. Estimated $\mathrm{N}_{2}$-fixation rates and abundances of the most dominant filamentous diazotroph, A. flosaquae, remained very low; therefore diazotrophs probably only made a minor contribution to overall $\mathrm{N}$ supply in this plankton community. Hence we did not observe relief of $\mathrm{N}$ limitation and stimulation of a summer plankton bloom of non-diazotrophic organisms. Indeed, dissolved inorganic nitrate present increased throughout the experiment, indicating higher supply than consumption, despite a considerable phosphate excess present.

We detected no significant differences in $\mathrm{N}$ pool sizes between $\mathrm{CO}_{2}$ treatments apart from the PON pool. However, the detected positive effect of $\mathrm{CO}_{2}$ on PON standing stocks was minor ( $<3 \%$ difference in PON concentration). Thus $\mathrm{N}$ uptake rates were well balanced with supply or any net $\mathrm{CO}_{2}-$ related differences were too small to be detected in $\mathrm{N}$ pool sizes across the range of simulated ocean acidification scenarios. In addition, we found no conclusive evidence from our data until $t 21\left(\mathrm{~N}_{2}\right.$-fixation rates, A. flos-aquae abundances, natural $\delta^{15} \mathrm{~N}$ abundances) that $\mathrm{CO}_{2}$ had a measurable impact on $\mathrm{N}$ inputs via diazotrophy. The absence of any detectable effect may have been influenced by the low abundances of filamentous diazotrophic cyanobacteria in this study. However, the lack of response was consistent with other studies of diazotrophic organisms in natural plankton communities, where resource competition with other plankton functional groups and top-down control may also play important roles in mediating the physiological response of $\mathrm{N}_{2}$-fixing organisms. 
Nonetheless, it appears that increased $\mathrm{CO}_{2}$ may have slightly enhanced the ability of the N-limited plankton community in the Baltic Sea to exploit the low N sources available, thereby potentially explaining lower phosphate concentrations, higher particulate matter concentrations and $\mathrm{Chl} a$ observed under higher $\mathrm{CO}_{2}$ (Paul et al., 2015). However, we have no direct evidence of increased new $\mathrm{N}$ inputs via diazotrophy or changed $\mathrm{N}$ biogeochemistry within the first 3 weeks and no conclusive indirect evidence from $\mathrm{N}$ pool sizes up to 6 weeks after $\mathrm{CO}_{2}$ manipulation. Therefore we conclude that elevated $\mathrm{CO}_{2}$ had no observable impact on the $\mathrm{N}$ cycle in this summer Baltic Sea plankton community.

\section{The Supplement related to this article is available online at doi:10.5194/bg-13-3901-2016-supplement.}

Acknowledgements. We would like to thank Douglas Campbell and one anonymous referee for their constructive comments, which improved the manuscript during the review process. We thank the KOSMOS team and all of the participants in the mesocosm campaign for their contribution to the mesocosm sampling during the experiment. In particular, we would like to thank Andrea Ludwig for co-ordinating the campaign logistics and assistance with CTD operations, the diving team, as well as Kerstin Nachtigall for analyses. Thank you also to Dana Hellemann, FrancoisEric Legiret, Jana Meyer, Michael Meyerhöfer, Jehane Ouriqua and Michael Sswat for assistance in sampling and analyses. We would also like to sincerely thank the Tvärminne Zoological Station for their warm hospitality, support and use of facilities for this experiment. We also gratefully acknowledge the captain and crew of R/V ALKOR for their work transporting, deploying and recovering the mesocosms. This collaborative project was funded by the Cluster of Excellence "The Future Ocean" (project CP1141) and by BMBF projects BIOACID II (FKZ 03F06550), SOPRAN Phase II (FKZ 03F0611) and MESOAQUA (grant agreement number 228224).

The article processing charges for this open-access publication were covered by a Research

Centre of the Helmholtz Association.

Edited by: J.-P. Gattuso

\section{References}

Almén, A.-K., Vehmaa, A., Brutemark, A., and EngströmÖst, J.: Coping with climate change? Copepods experience drastic variations in their physicochemical environment on a diurnal basis, J. Exp. Mar. Biol. Ecol., 460, 120-128, doi:10.1016/j.jembe.2014.07.001, 2014.

Badr, E.-S. A., Achterberg, E. P., Tappin, A. D., Hill, S. J., and Braungardt, C. B.: Determination of dissolved organic nitrogen in natural waters using high-temperature catalytic oxidation,
TrAC-Trend, Anal. Chem., 22, 819-827, doi:10.1016/S01659936(03)01202-0, 2003.

Barcelos e Ramos, J., Biswas, H., Schulz, K., LaRoche, J., and Riebesell, U.: Effect of rising atmospheric carbon dioxide on the marine nitrogen fixer Trichodesmium, Global Biogeochem. Cy., 21, GB2028, doi:10.1029/2006GB002898, 2007.

Barlow, R. G., Cummings, D. G., and Gibb, S. W.: Improved resolution of mono- and divinyl chlorophylls $a$ and $b$ and zeaxanthin and lutein in phytoplankton extracts using reverse phase C-8 HPLC, Mar. Ecol.-Prog. Ser., 161, 303-307, doi:10.3354/meps161303, 1997.

Bentzon-Tilia, M., Traving, S. J., Mantikci, M., Knudsen-Leerbeck, H., Hansen, J. L. S., Markager, S., and Riemann, L.: Significant $\mathrm{N}_{2}$ fixation by heterotrophs, photoheterotrophs and heterocystous cyanobacteria in two temperate estuaries, ISME J., 9, 273285, doi:10.1038/ismej.2014.119, 2015.

Böttjer, D., Karl, D. M., Letelier, R. M., Viviani, D. A., and Church, M. J.: Experimental assessment of diazotroph responses to elevated seawater $p \mathrm{CO}_{2}$ in the North Pacific Subtropical Gyre, Global Biogeochem. Cy., 28, 601-616, doi:10.1002/2013GB004690, 2014.

Boxhammer, T., Bach, L. T., Czerny, J., and Riebesell, U.: Technical note: Sampling and processing of mesocosm sediment trap material for quantitative biogeochemical analysis, Biogeosciences, 13, 2849-2858, doi:10.5194/bg-13-2849-2016, 2016.

Brutemark, A., Engström-Öst, J., and Vehmaa, A.: Long-term monitoring data reveal $\mathrm{pH}$ dynamics, trends and variability in the western Gulf of Finland, Oceanol. Hydrobiol. St., 40, 91-94, doi:10.2478/s13545-011-0034-3, 2011.

Czerny, J., Barcelos e Ramos, J., and Riebesell, U.: Influence of elevated $\mathrm{CO}_{2}$ concentrations on cell division and nitrogen fixation rates in the bloom-forming cyanobacterium Nodularia spumigena, Biogeosciences, 6, 1865-1875, doi:10.5194/bg-6-18652009, 2009.

Dabundo, R., Lehmann, M. F., Treibergs, L., Tobias, C. R., Altabet, M. A., Moisander, P. H., and Granger, J.: The contamination of commercial ${ }^{15} \mathrm{~N}_{2}$ gas stocks with ${ }^{15} \mathrm{~N}$-labeled nitrate and ammonium and consequences for nitrogen fixation measurements, PLoS ONE, 9, e110335, doi:10.1371/journal.pone.0110335, 2014.

Derenbach, J.: Zur Homogenisation des Phytoplanktons für die Chlorophyllbestimmung, Kieler Meeresforschungen, 25, 166171, 1969.

Deutsch, C., Sarmiento, J. L., Sigman, D. M., Gruber, N., and Dunne, J. P.: Spatial coupling of nitrogen inputs and losses in the ocean, Nature, 445, 163-167, doi:10.1038/nature05392, 2007.

Dugdale, R. and Goering, J.: Uptake of new and regenerated forms of nitrogen in primary productivity, Limnol. Oceanogr., 12, 196206, 1967.

Eichner, M., Rost, B., and Kranz, S. A.: Diversity of ocean acidification effects on marine $\mathrm{N}_{2}$ fixers, J. Exp. Mar. Biol. Ecol., 457, 199-207, doi:10.1016/j.jembe.2014.04.015, 2014.

Engström-Öst, J., Hogfors, H., El-Shehawy, R., De Stasio, B., Vehmaa, A., and Gorokhova, E.: Toxin-producing cyanobacterium Nodularia spumigena, potential competitors and grazers: testing mechanisms of reciprocal interactions, Aquat. Microb. Ecol., 62, 39-48, doi:10.3354/ame01456, 2011.

Farnelid, H., Oberg, T., and Riemann, L.: Identity and dynamics of putative $\mathrm{N}_{2}$-fixing picoplankton in the Baltic Sea proper suggest 
complex patterns of regulation, Environ. Microbiol. Reports, 1, 145-154, doi:10.1111/j.1758-2229.2009.00021.x, 2009.

Farnelid, H., Bentzon-Tilia, M., Andersson, A. F., Bertilsson, S., Jost, G., Labrenz, M., Jürgens, K., and Riemann, L.: Active nitrogen-fixing heterotrophic bacteria at and below the chemocline of the central Baltic Sea, ISME J., 7, 1413-1423, doi:10.1038/ismej.2013.26, 2013.

Fu, F., Mulholland, M., Garcia, N., Beck, A., Bernhardt, P., Warner, M., Sanudo-Wilhelmy, S., and Hutchins, D.: Interactions between changing $p \mathrm{CO}_{2}, \mathrm{~N}_{2}$ fixation, and $\mathrm{Fe}$ limitation in the marine unicellular cyanobacterium Crocosphaera, Limnol. Oceanogr., 53, 2472-2484, 2008.

Gustafsson, Ö., Gelting, J., Andersson, P., Larsson, U., and Roos, P.: An assessment of upper ocean carbon and nitrogen export fluxes on the boreal continental shelf: A 3-year study in the open Baltic Sea comparing sediment traps, ${ }^{234}$ Th proxy, nutrient, and oxygen budgets, Limnol. Oceanogr.-Meth, 11, 495-510, doi:10.4319/lom.2013.11.495, 2013.

Halm, H., Lam, P., Ferdelman, T. G., Lavik, G., Dittmar, T., LaRoche, J., D'Hondt, S., and Kuypers, M. M. M.: Heterotrophic organisms dominate nitrogen fixation in the South Pacific Gyre, ISME J., 6, 1238-1249, doi:10.1038/ismej.2011.182, 2012.

Hansen, H. P. and Koroleff, F.: Determination of nutrients, in: Methods of Seawater Analysis, edited by: Grasshoff, K., Kremling, K., and Ehrhardt, M., 159-228, Wiley Verlag Chemie GmbH, Weinheim, Germany, 1999.

HELCOM: Manual for Marine Monitoring in the COMBINE Programme of HELCOM, Helsinki Commission, Helsinki, available at: http://www.helcom.fi/Documents/Action\% 20areas/Monitoring\%20and\%20assessment/Manuals\%20and\% 20Guidelines/Manual\%20for\%20Marine\%20Monitoring\% 20in\%20the $\% 20$ COMBINE\%20Programme $\% 20$ of $\%$ 20HELCOM.pdf, 2012.

Hogfors, H., Motwani, N. H., Hajdu, S., El-Shehawy, R., Holmborn, T., Vehmaa, A., Engström-Öst, J., Brutemark, A., and Gorokhova, E.: Bloom-forming cyanobacteria support copepod reproduction and development in the Baltic Sea, PLoS One, 9, e112692, doi:10.1371/journal.pone.0112692, 2014.

Hoppenrath, M., Elbrächter, M., and Drebes, G. (Eds.): Marine phytoplankton, Schweizerbart Science Publishers, Stuttgart, Germany, 2009.

Hutchins, D., Fu, F., Zhang, Y., Warner, M., Feng, Y., Portune, K., Bernhardt, P., and Mulholland, M.: $\mathrm{CO}_{2}$ control of Trichodesmium $\mathrm{N}_{2}$ fixation, photosynthesis, growth rates, and elemental ratios: Implications for past, present, and future ocean biogeochemistry, Limnol. Oceanogr., 52, 1293-1304, 2007.

Hutchins, D. A., Fu, F.-X., Webb, E. A., Walworth, N., and Tagliabue, A.: Taxon-specific response of marine nitrogen fixers to elevated carbon dioxide concentrations, Nat. Geosci., advance online publication, doi:10.1038/ngeo1858, 2013.

Kahru, M. and Elmgren, R.: Multidecadal time series of satellitedetected accumulations of cyanobacteria in the Baltic Sea, Biogeosciences, 11, 3619-3633, doi:10.5194/bg-11-3619-2014, 2014.

Kérouel, R. and Aminot, A.: Fluorometric determination of ammonia in sea and estuarine waters by direct segmented flow analysis, Mar. Chem., 57, 265-275, doi:10.1016/S0304-4203(97)00040-6, 1997.
Kirkkala, T., Helminen, H., and Erkkilä, A.: Variability of nutrient limitation in the Archipelago Sea, SW Finland, Hydrobiologia, 363, 117-126, doi:10.1023/A:1003192831321, 1997.

Kononen, K., Kuparinen, J., Mäkelä, K., Laanemets, J., Pavelson, J., and Nõmmann, S.: Initiation of cyanobacterial blooms in a frontal region at the entrance to the Gulf of Finland, Baltic Sea, Limnol. Oceanogr., 41, 98-112, doi:10.4319/lo.1996.41.1.0098, 1996.

Kraberg, A., Baumann, M., and Durselen, C.-D.: Coastal Phytoplankton: Photo Guide for Northern European Seas, Pfeil, Munich, Germany, 2010.

Kranz, S. A., Levitan, O., Richter, K.-U., Prasil, O., BermanFrank, I., and Rost, B.: Combined effects of $\mathrm{CO}_{2}$ and light on the $\mathrm{N}_{2}$-fixing cyanobacterium Trichodesmium IMS101: Physiological responses, Plant Physiol., 154, 334-345, doi:10.1104/pp.110.159145, 2010.

Kuparinen, J.: Production and respiration of overall plankton and ultraplankton communities at the entrance to the Gulf of Finland in the Baltic Sea, Mar. Biol., 93, 591-607, doi:10.1007/BF00392797, 1987.

Laamanen, M. and Kuosa, H.: Annual variability of biomass and heterocysts of the $\mathrm{N}_{2}$-fixing cyanobacterium Aphanizomenon flos-aquae in the Baltic Sea with reference to Anabaena spp. and Nodularia spumigena, Boreal Environ. Res., 10, 19-30, 2005.

Law, C. S., Breitbarth, E., Hoffmann, L. J., McGraw, C. M., Langlois, R. J., LaRoche, J., Marriner, A., and Safi, K. A.: No stimulation of nitrogen fixation by non-filamentous diazotrophs under elevated $\mathrm{CO}_{2}$ in the South Pacific, Glob. Change Biol., 18, 30043014, doi:10.1111/j.1365-2486.2012.02777.x, 2012.

Levitan, O., Rosenberg, G., Setlik, I., Setlikova, E., Grigel, J., Klepetar, J., Prasil, O., and Berman-Frank, I.: Elevated $\mathrm{CO}_{2}$ enhances nitrogen fixation and growth in the marine cyanobacterium Trichodesmium, Glob. Change Biol., 13, 531538, doi:10.1111/j.1365-2486.2006.01314.x, 2007.

Lischka, S., Bach, L. T., Schulz, K.-G., and Riebesell, U.: Microand mesozooplankton community response to increasing $\mathrm{CO}_{2}$ levels in the Baltic Sea: insights from a large-scale mesocosm experiment, Biogeosciences Discuss., 12, 20025-20070, doi:10.5194/bgd-12-20025-2015, 2015.

Loescher, C. R., Großkopf, T., Desai, F. D., Gill, D., Schunck, H., Croot, P. L., Schlosser, C., Neulinger, S. C., Pinnow, N., Lavik, G., Kuypers, M. M. M., LaRoche, J., and Schmitz, R. A.: Facets of diazotrophy in the oxygen minimum zone waters off Peru, ISME J., 8, 2180-2192, doi:10.1038/ismej.2014.71, 2014.

Menden-Deuer, S. and Lessard, E. J.: Carbon to volume relationships for dinoflagellates, diatoms, and other protist plankton, Limnol. Oceanogr., 45, 569-579, doi:10.4319/lo.2000.45.3.0569, 2000.

Mohr, W., Grosskopf, T., Wallace, D., and LaRoche, J.: Methodological underestimation of oceanic nitrogen fixation rates, PLoS One, 5, e12583, doi:10.1371/journal.pone.0012583, 2010.

Moisander, P. H., Beinart, R. A., Hewson, I., White, A. E., Johnson, K. S., Carlson, C. A., Montoya, J. P., and Zehr, J. P.: Unicellular cyanobacterial distributions broaden the oceanic $\mathrm{N}_{2}$ fixation domain, Science, 327, 1512-1514, doi:10.1126/science.1185468, 2010.

Montoya, J. P., Voss, M., Kahler, P., and Capone, D. G.: A simple, high-precision, high-sensitivity tracer assay for $\mathrm{N}_{2}$ fixation, Appl. Environ. Microbiol., 62, 986-993, 1996. 
Moore, C. M., Mills, M. M., Langlois, R., Milne, A., Achterberg, E. P., La Roche, J., and Geider, R. J.: Relative influence of nitrogen and phosphorous availability on phytoplankton physiology and productivity in the oligotrophic subtropical North Atlantic Ocean, Limnol. Oceanogr., 53, 291-305, doi:10.4319/lo.2008.53.1.0291, 2008.

Moore, C. M., Mills, M. M., Arrigo, K. R., Berman-Frank, I., Bopp, L., Boyd, P. W., Galbraith, E. D., Geider, R. J., Guieu, C., Jaccard, S. L., Jickells, T. D., La Roche, J., Lenton, T. M., Mahowald, N. M., Marañón, E., Marinov, I., Moore, J. K., Nakatsuka, T., Oschlies, A., Saito, M. A., Thingstad, T. F., Tsuda, A., and Ulloa, O.: Processes and patterns of oceanic nutrient limitation, Nat. Geosci., 6, 701-710, doi:10.1038/ngeo1765, 2013.

Nausch, M., Bach, L. T., Czerny, J., Goldstein, J., Grossart, H.-P., Hellemann, D., Hornick, T., Achterberg, E. P., Schulz, K.-G., and Riebesell, U.: Effects of $\mathrm{CO}_{2}$ perturbation on phosphorus pool sizes and uptake in a mesocosm experiment during a low productive summer season in the northern Baltic Sea, Biogeosciences, 13, 3035-3050, doi:10.5194/bg-13-3035-2016, 2016.

Ohlendieck, U., Stuhr, A., and Siegmund, H.: Nitrogen fixation by diazotrophic cyanobacteria in the Baltic Sea and transfer of the newly fixed nitrogen to picoplankton organisms, J. Marine Syst., 25, 213-219, doi:10.1016/S0924-7963(00)00016-6, 2000.

Ohlendieck, U., Gundersen, K., Meyerhöfer, M., Fritsche, P., Nachtigall, K., and Bergmann, B.: The significance of nitrogen fixation to new production during early summer in the Baltic Sea, Biogeosciences, 4, 63-73, doi:10.5194/bg-4-63-2007, 2007.

Olenina, I., Hajdu, S., Edler, L., Andersson, A., Wasmund, N., Busch, S., Göbel, J., Gromisz, S., Huseby, S., Huttunen, M., Jaanus, A., Kokkonen, P., Ledaine, I., and Niemkiewicz, E.: Biovolumes and size-classes of phytoplankton in the Baltic Sea, HELCOM Baltic Sea Environment Proceedings No. 106, 144, 2006.

Patey, M. D., Rijkenberg, M. J. A., Statham, P. J., Stinchcombe, M. C., Achterberg, E. P., and Mowlem, M.: Determination of nitrate and phosphate in seawater at nanomolar concentrations, TrAC-Trend. Anal. Chem., 27, 169-182, doi:10.1016/j.trac.2007.12.006, 2008.

Paul, A. J., Bach, L. T., Schulz, K.-G., Boxhammer, T., Czerny, J., Achterberg, E. P., Hellemann, D., Trense, Y., Nausch, M., Sswat, M., and Riebesell, U.: Effect of elevated $\mathrm{CO}_{2}$ on organic matter pools and fluxes in a summer Baltic Sea plankton community, Biogeosciences, 12, 6181-6203, doi:10.5194/bg-12-6181-2015, 2015.

Pliński, M. and Jóźwiak, T.: Temperature and N : P ratio as factors causing blooms of blue-green algae in the Gulf of Gdańsk, Oceanologia, 41, 73-80, 1999.

Ploug, H.: Cyanobacterial surface blooms formed by Aphanizomenon sp. and Nodularia spumigena in the Baltic Sea: Small-scale fluxes, $\mathrm{pH}$, and oxygen microenvironments, Limnol. Oceanogr., 53, 914-921, doi:10.4319/lo.2008.53.3.0914, 2008.

Ploug, H., Musat, N., Adam, B., Moraru, C. L., Lavik, G., Vagner, T., Bergman, B., and Kuypers, M. M. M.: Carbon and nitrogen fluxes associated with the cyanobacterium Aphanizomenon sp. in the Baltic Sea, ISME J., 4, 1215-1223, doi:10.1038/ismej.2010.53, 2010.

R Core Team: A language and environment for statistical computing, R Foundation for Statistical Computing, Vienna, Austria, available at: https://www.R-project.org/, 2015.
Riebesell, U., Czerny, J., von Bröckel, K., Boxhammer, T., Büdenbender, J., Deckelnick, M., Fischer, M., Hoffmann, D., Krug, S. A., Lentz, U., Ludwig, A., Muche, R., and Schulz, K. G.: Technical Note: A mobile sea-going mesocosm system - new opportunities for ocean change research, Biogeosciences, 10, 18351847, doi:10.5194/bg-10-1835-2013, 2013.

Sahlsten, E. and Sörensson, F.: Planktonic nitrogen transformations during a declining cyanobacteria bloom in the Baltic Sea, J. Plankton Res., 11, 1117-1128, 1989.

Schluter, L., Garde, K., and Kaas, H.: Detection of the toxic cyanobacteria Nodularia spumigena by means of a 4-ketomyxoxanthophyll-like pigment in the Baltic Sea, Mar. Ecol.Prog. Ser., 275, 69-78, doi:10.3354/meps275069, 2004.

Shapiro, J.: The role of carbon dioxide in the initiation and maintenance of blue-green dominance in lakes, Freshwater Biol., 37, 307-323, doi:10.1046/j.1365-2427.1997.00164.x, 1997.

Sharp, J.: Improved analysis for particulate organic carbon and nitrogen from seawater, Limnol. Oceanogr., 19, 984-989, 1974.

Shi, D., Kranz, S. A., Kim, J.-M., and Morel, F. M. M.: Ocean acidification slows nitrogen fixation and growth in the dominant diazotroph Trichodesmium under low-iron conditions, P. Natl. Acad. Sci. USA, 109, E3094-E3100, doi:10.1073/pnas.1216012109, 2012.

Stal, L. J., Albertano, P., Bergman, B., Bröckel, K. von, Gallon, J. R., Hayes, P. K., Sivonen, K., and Walsby, A. E.: BASIC: Baltic Sea cyanobacteria. An investigation of the structure and dynamics of water blooms of cyanobacteria in the Baltic Sea - responses to a changing environment, Cont. Shelf Res., 23, 16951714, doi:10.1016/j.csr.2003.06.001, 2003.

Tamminen, T.: Nitrate and ammonium depletion rates and preferences during a Baltic spring bloom, Mar. Ecol.-Prog. Ser., 120, 123-133, 1995.

Tamminen, T. and Andersen, T.: Seasonal phytoplankton nutrient limitation patterns as revealed by bioassys over Baltic Sea gradients of salinity and eutrophication, Mar. Ecol.-Prog. Ser., 340, 121-138, 2007.

Tomas, C. R.: Identifying Marine Phytoplankton, Academic Press, San Diego, USA/London, United Kingdom, 1997.

Utermöhl, H.: Vervollkummnung der quantitativen PhytoplanktonMethodik, Mitteilungen der Internationalen Vereinigung für Limnologie, 9, 1-38, 1958.

Vahtera, E., Conley, D. J., Gustafsson, B. G., Kuosa, H., Pitkänen, H., Savchuk, O. P., Tamminen, T., Viitasalo, M., Voss, M., Wasmund, N., and Wulff, F.: Internal ecosystem feedbacks enhance nitrogen-fixing cyanobacteria blooms and complicate management in the Baltic Sea, AMBIO, 36, 186-194, doi:10.1579/00447447(2007)36[186:IEFENC]2.0.CO;2, 2007.

Vitousek, P. M. and Howarth, R. W.: Nitrogen limitation on land and in the sea: How can it occur?, Biogeochemistry, 13, 87-115, doi:10.1007/BF00002772, 1991.

Wannicke, N., Endres, S., Engel, A., Grossart, H.-P., Nausch, M., Unger, J., and Voss, M.: Response of Nodularia spumigena to $p \mathrm{CO}_{2}$ - Part 1: Growth, production and nitrogen cycling, Biogeosciences, 9, 2973-2988, doi:10.5194/bg-9-2973-2012, 2012.

Wannicke, N., Korth, F., Liskow, I., and Voss, M.: Incorporation of diazotrophic fixed $\mathrm{N}_{2}$ by mesozooplankton - Case studies in the southern Baltic Sea, J. Marine Syst., 117-118, 1-13, doi:10.1016/j.jmarsys.2013.03.005, 2013. 
Wasmund, N.: Occurrence of cyanobacterial blooms in the Baltic Sea in relation to environmental conditions, Internationale Revue Der Gesamten Hydrobiologie, 82, 169-184, doi:10.1002/iroh.19970820205, 1997.

Wasmund, N., Voss, M., and Lochte, K.: Evidence of nitrogen fixation by non-heterocystous cyanobacteria in the Baltic Sea and re-calculation of a budget of nitrogen fixation, Mar. Ecol.-Prog. Ser., 214, 1-14, doi:10.3354/meps214001, 2001.

Yamamoto, Y.: Environmental factors that determine the occurrence and seasonal dynamics of Aphanizomenon flos-aquae, J. Limnol., 68, 122-132, 2009.
Yamamoto, Y. and Nakahara, H.: The formation and degradation of cyanobacterium Aphanizomenon flos-aquae blooms: the importance of $\mathrm{pH}$, water temperature, and day length, Limnology, 6, 1-6, doi:10.1007/s10201-004-0138-1, 2005.

Zehr, J. P., Bench, S. R., Carter, B. J., Hewson, I., Niazi, F., Shi, T., Tripp, H. J., and Affourtit, J. P.: Globally distributed uncultivated oceanic $\mathrm{N}_{2}$-fixing cyanobacteria lack oxygenic photosystem II, Science, 322, 1110-1112, doi:10.1126/science.1165340, 2008.

Zhang, J.-Z. and Chi, J.: Automated analysis of nanomolar concentrations of phosphate in natural waters with liquid waveguide, Environ. Sci. Technol., 36, 1048-1053, doi:10.1021/es011094v, 2002. 